\title{
ASSESSMENT OF HEAVY METALS CONCENTRATION OF DUMPSITES SOILS USED FOR AMARANTHUS PRODUCTION IN IMO STATE, NIGERIA
}

\author{
Chikere - Njoku C ${ }^{1}$; C.C. Onyeanuforo ${ }^{1}$ and M.O. Onuh ${ }^{2}$ \\ ${ }^{1}$ Department of soil science and Environment Imo State University, Nigeria. \\ ${ }^{2}$ Department of crop science and Biotechnology Imo State University, Nigeria. \\ DOI: https://doi.org/10.51193/IJAER.2021.7206
}

\begin{abstract}
Vegetable production on dumpsites soils in Imo State has become popular owing to quicker biomass production and income generation. Sequel to this, an assessment of heavy metals in such soils was conducted at Irette, Ogbaku, Orogwe, Nekede and Akwakuma dumpsites alongside areas without refuse dumps (control sites).soil samples were collected from each dumpsites as well as from control sites using soil auger at the depth of $0-20 \mathrm{~cm}$. vegetable (Amaranth) was collected from each dumpsite and control sites. Both soil and Amaranth were prepared and analyzed for heavy metals: Cadmium (Cd), Chromium (Cr), Copper ( $\mathrm{Cu}$ ) and Zinc (Zn). Results showed that heavy metal concentrations of soil and in Amaranthus cultivated on soils characterized in dumpsites are significantly $(\mathrm{P}=0.05)$ higher than the adjacent (control) sites. also result showed that $\mathrm{Cr}, \mathrm{Cu}$ and $\mathrm{Zn}$ contents of soil are lower $(3.06,109.70$ and $21.29 \mathrm{mg} / \mathrm{kg}$ respectively) than recommended limit by World Health Organization (1996) (100,140 and 50 $\mathrm{mg} / \mathrm{kg}$ respectively), the range within the vegetable (amaranth) were above the normal limit suggesting that vegetable has a way of concentrating metals in their tissues. Therefore based on this study, farmers should avoid growing vegetables (Amaranth) in dumps to avoid food contamination and health hazard.
\end{abstract}

Keywords: Heavy Metals, soil, Amaranthus Cruentus L., Waste, Pollution.

\section{INTRODUCTION}

Soils have usually been contaminated by many anthropogenic activities, and the pollutants have always been in form of industrial effluents, municipal sewage water and many unwanted wastes like plastic materials and broken pieces of metal. Among these pollutants, heavy metals 
International Journal of Agriculture and Environmental Research

ISSN: 2455-6939

Volume: 07, Issue: 02 "March-April 2021"

constitutes serious danger to humans and animals when they consume vegetables produced from the polluted areas.

Heavy metals are natural constituents of the earth's crust. Studies have shown that these elements accumulate and persist in soils at environmentally hazardous levels (Odukoya et al., 2000). Recent studies showed that soils of refuse dumpsites contain different kinds and concentration of heavy metals (Odukoya, 2015).

Food contamination by heavy metals has become a burning issue in recent years because of their potential hazards in biosystems (Begum et al., 2009). Heavy metals can accumulate in soils, water and air to toxic levels as a result of long term application of untreated waste water and fertilizers. Soils being irrigated by waste water can accumulate heavy metals in the surface and when the capacity to retain heavy metals is reduced due to repeated application of waste water, heavy metals will leach into soil and become available for plant uptake (Odukoya, 2015). The heavy metal pollutants include: Cadmium, Chromium, Copper and Zinc.

The risky nature of heavy metals has been recognized because of their bio - accumulative nature in biotic systems, plants absorb heavy metals from the soil through their roots. Heavy metals poisoning arises from toxic properties being released, leading to adverse effects on humans and ecosystem (Voet et al., 2008).

Increase in human population and civilization in Imo State have increased the number of dumpsites due to poor waste management. It has been a common practice in Imo state to burn dumpsites waste and thus gets rid of organic matter, generating ashes which are richer in heavy metals content. These ashes will dissolve in rain water and be leached into the soil, causing contamination of the underground water or be washed away by run-off into streams and rivers, thereby contaminating the environment.

Heavy metals are hazardous in human body due to their ability to cause cancer and other health problems. The determination of levels of such heavy metals in soils will go a long way in suggesting remedial measures, to avoid the soil being used to grow crops, especially vegetables leading to transfer of heavy metals into the human body. The objective of this study was to assess the heavy metal (Chromium Cadmium and Copper and Zinc) contents in dumpsite soils and vegetable (Amaranthus cruensis) grown with dumpsites soil in Owerri, Imo State, Nigeria.

\section{MATERIALS AND METHODS}

\section{Study Area}


International Journal of Agriculture and Environmental Research

ISSN: 2455-6939

Volume: 07, Issue: 02 "March-April 2021"

This study was conducted within Owerri, Imo State, Nigeria. Owerri is in the Southeast Agro ecological Zone of Nigeria and is located at $5^{0} 30^{\prime}$ and $5^{\circ} 57^{\prime} \mathrm{N}$ and longitude $7^{0} 04^{\prime}$ and $7^{0} 26^{\prime} \mathrm{E}$. Soils are derived from coastal plain sand (Ofomata 1975). It lies within the humid tropics with annual rainfall of about $2500 \mathrm{~mm}$ and rainfall pattern is bimodal.

\section{Sample Collection}

The sampling sites are five (5) main dumpsites, they are located at Irette, Ogbaku, Orogwe, Nekede and Akwakuma. Each dumpsite has its control located at few kilometers where there was no dumpsite.

The areas were cleared using cutlass and marked with carved wooden peg. The field was slightly cleared to create a footpath. At each of the dumpsites and control, a study site of $15 \times 30 \mathrm{~m}$ was measured with a measuring tape, demarcated with wooden pegs and rope. A systematic sampling approach comprising three line - transects of $5 \mathrm{~m}$ intervals was used. Within each of the line transect, three sample plots of $10 \mathrm{~m}$ interval were located. A total of nine (9) sample plots of $2 \times 2 \mathrm{~m}$ were used for the exercise in each study site. The soil samples were collected at each plot both dumpsites and control sites using s soil auger at the depth of $0-20 \mathrm{~cm}$. The soil samples were put in black polythene bags, tied and labeled appropriately and taken to the laboratory for heavy metal analysis. Vegetable (Amaranth) was planted and harvested after five (5) weeks from both dumpsites and the control. Plant sampling was done by uprooting, washing in distill water to remove soil particles from the roots. They were also put in black polythene bags, well labeled and taken to the laboratory for heavy metals cadmium $(\mathrm{Cd})$, Chromium $(\mathrm{Cr})$, Copper $(\mathrm{Cu})$ and Zinc $(\mathrm{Zn})$ analysis.

Heavy Metal Analysis of Soil Samples: The soil samples were air dried and sieved with a $2 \mathrm{~mm}$ sieve. Sieved samples were weighed into a digestion flask. $20 \mathrm{ml}$ of concentrated nitric acid was added and the mixture was digested using hot plate. After digestion, it was allowed to cool and $30 \mathrm{ml}$ of distilled water was added and the mixture was filtered using Whatman filter paper. The digest was made upto $50 \mathrm{ml}$ solution with distilled water. The digest samples were analyzed for heavy metals: Cadmium, Chromium, Copper and Zinc using Atomic Absorption Spectrometer (AAS VGB 210 System).

Heavy Metal Analysis of Plant Sample: The vegetable (Amaranth) samples were oven dried to constant weight. The vegetable materials were ground to fine powder. One (1) gram of the sample was weighed into the crucible and ashed for four (4) hours at $600^{\circ} \mathrm{C}$. It was then allowed to cool. $10 \%$ nitric acid was added and filtered using Whatman filter paper. The digest was made upto $50 \mathrm{ml}$ solution with distilled water and determined using Atomic Absorption Spectrometer 
International Journal of Agriculture and Environmental Research

ISSN: $2455-6939$

Volume: 07, Issue: 02 "March-April 2021"

(AAS VGB 210 System). The heavy metals read include: Cadmium, Chromium, Copper and Zinc.

\section{Statistical Analysis}

Data generated were subjected to analysis of variance using Statistical Analysis Software (SAS) and significantly different treatment means were separated at $5 \%$ level of probability using LSD range test.

\section{RESULTS AND DISCUSSION}

Table 1 shows the heavy metal concentrations in soils for five dumpsites and adjacent (control) sites at the depth of $0-20 \mathrm{~cm}$.

Cadmium (Cd): Cadmium content in dumpsites ranged from 3.70 to $7.20 \mathrm{mg} / \mathrm{kg}$ with mean content of $5.80 \mathrm{mg} / \mathrm{kg}$ while the adjacent (control) values ranged from 0.04 to $0.41 \mathrm{mg} / \mathrm{kg}$ with mean content of $0.22 \mathrm{mg} / \mathrm{kg}$. Cadmium content in dumpsites soils are significantly higher $(\mathrm{P}<0.05)$ than adjacent (control) sites (Table 3). Cadmium concentrations in the soils were above the standard limits $(0.01 \mathrm{mg} / \mathrm{kg}$ ) of Federal Environmental Protection Agency (FEPA) 1991 and $(3.0 \mathrm{mg} / \mathrm{kg}$ ) set by the European commission (1998). The higher contents of metals around dumpsites is due to wastes, which originates mostly from domestic and industrial activities which generate wastes and refuse that are sources of these heavy metals (Aekala et al, 2008).

Chromium (Cr): The contents of Chromium in the dumpsites was found in the range of 2.00 to $4.80 \mathrm{mg} / \mathrm{kg}$ (Table 1) with mean content of $3.06 \mathrm{mg} / \mathrm{kg}$ (Table 3), while the adjacent (control) sites ranged from 0.08 to $1.14 \mathrm{mg} / \mathrm{kg}$. Although the values at dumpsites were higher than the adjacent (control) sites, they are below permissible limit recommended by Dutch Standard (100 $\mathrm{mg} / \mathrm{kg}$ ) for Chromium. All the soil samples were below the permissible limit in this study.

Copper (Cu): Copper contents in dumpsite soils ranged from 21.10 to $155.23 \mathrm{mg} / \mathrm{kg}$ with mean content of $109.70 \mathrm{mg} / \mathrm{kg}$ while adjacent (control) sites ranged from 11.10 to $19.40 \mathrm{mg} / \mathrm{kg}$ (Table 1), with mean content of $17.94 \mathrm{mg} / \mathrm{kg}$ (Table 3). The concentration at dumpsites were highly significant $(\mathrm{P}=0.01)$ than control sites. $\mathrm{Cu}$ contents were below the standard limits $(140 \mathrm{mg} / \mathrm{kg})$ set by World Health Organization (WHO) and European Commission (1986). The high concentration of $\mathrm{Cu}$ at dumpsites may be attributed to burnt vehicles because $\mathrm{Cu}$ is commonly found in electrical wirings and the $\mathrm{Cu}$ content of other solid wastes deposited indiscrimately in the area. 
International Journal of Agriculture and Environmental Research

ISSN: 2455-6939

Volume: 07, Issue: 02 "March-April 2021"

Zinc (Zn): The concentration of zinc in dumpsites soils ranged from 15.73 to $33.64 \mathrm{mg} / \mathrm{kg}$ with mean content of 21.29 while control sites had values that ranged from 2.61 to $4.28 \mathrm{mg} / \mathrm{kg}$ with mean content of $3.24 \mathrm{mg} / \mathrm{kg}$. $\mathrm{Zn}$ content at dumpsites are significantly higher $(\mathrm{P}<0.05)$ than adjacent (control) sites (Table 3), although the soils were below recommended limit (50 mg/kg) by World Health Organization (1996).

Heavy metal content of vegetable (Amaranthus Viridis): Table 2 shows the level of heavy metals $(\mathrm{Cd}, \mathrm{Cr}, \mathrm{Cu}$ and $\mathrm{Zn})$ in vegetable (Amaranthus Viridis) Cadmium (Cd); Cadmium concentration in vegetable (Amaranth) in dumpsites ranged from 5.16 to $18.60 \mathrm{mg} / \mathrm{kg}$ with mean content of $11.50 \mathrm{mg} / \mathrm{kg}$, while the content at adjacent (control) sites ranged from 0.08 to 0.02 $\mathrm{mg} / \mathrm{kg}$ with mean content of $0.12 \mathrm{mg} / \mathrm{kg}$. (Tables 2 and 3). The Cadmium content at dumpsites are significantly higher than the adjacent (control) sites $(\mathrm{P}=0.1)$. The concentrations in the vegetable (Amaranthus) were above the standard limit of $0.02 \mathrm{mg} / \mathrm{kg}$ set by WHO (1996). The high concentration of $\mathrm{Cd}$ obtained in all the sites (dump and adjacent sites) may be due to industrial and agricultural applications. Numerous compounds of $\mathrm{Cd}$ are used in the chemical industries and in the manufacture of pesticides, herbicides used in agriculture (Alloway, 1998).

Chromium (Cr): The concentration of Chromium in the vegetable samples at dumpsites were found in the range of $3.21 \mathrm{mg} / \mathrm{kg}$ to $12.18 \mathrm{mg} / \mathrm{kg}$ with mean content of $7.21 \mathrm{mg} / \mathrm{kg}$ compared to the adjacent (control) sites that ranged from 0.01 to $0.09 \mathrm{mg} / \mathrm{kg}$ ( Table 2) with mean content of 0.05 (Table 3). The content in dumpsites were found to be greater than permissible limit which is $1.30 \mathrm{mg} / \mathrm{kg}$ recommended by WHO/FAO (1996). The higher concentration in the vegetable samples at dump sites may be as a result of the different sources from which they enter the air, water and soil and finally into food chain. Demirabas (2011) reported that accumulation of metals in edible vegetables such as waterleaf, green (Amaranth) is capable of poisoning communities that collect and eat these vegetables.

Copper (CU): copper contents in vegetables samples in dump sites ranged from 20.22 to 55.00 $\mathrm{mg} / \mathrm{kg}$ with mean content of $34.46 \mathrm{mg} / \mathrm{kg}$ while adjacent (Control) sites ranged from 0.10 to 0.99 $\mathrm{mg} / \mathrm{kg}$ with mean content of $0.49 \mathrm{mg} / \mathrm{kg}$ (Table 2). Cu content in the vegetable are significantly higher $(\mathrm{P}<0.05)$ in the dump sites than adjacent sites. Concentration of $\mathrm{Cu}$ at dump sites were above the permissible limit of $10 \mathrm{mg} / \mathrm{kg}$ set by WHO/FAO (1996 standard, while the adjacent sites are generally below the standard limit.

Zinc (Zn): Zinc content of vegetable ranged from 44.33 to $88.60 \mathrm{mg} / \mathrm{kg}$ with mean content of $59.82 \mathrm{mg} / \mathrm{kg}$ at dump and ranged from 0.21 to $0.38 \mathrm{mg} / \mathrm{kg}$ at adjacent (Control) sites with mean content $0.51 \mathrm{mg} / \mathrm{kg}$ (Table 2) the WHO/FAO permissible limit for $\mathrm{Zn}$ is $0.60 \mathrm{mg} / \mathrm{kg}$. The values at dump are significantly $(\mathrm{P}<0.05)$ higher in the dump sites than adjacent (Control) sites. The 
high concentration of $\mathrm{Zn}$ in vegetable may be attributed to the emissions that pass through these dump sites into the soil.

Correlation Results of Heavy Metal Contents of Dump Soils and Vegetables: Correlation coefficient (r) matrix was established for heavy metal concentration in the dump site soils and vegetable (amaranth). Table 5.

The correlations between heavy metal concentration in dump site soils and heavy metal concentration in vegetable (amaranth) is presented in table 5. The correlation analysis showed that Cadmium significantly $(\mathrm{P}<0.01)$ and positively correlated with Chromium $(\mathrm{r}=0.921 * *)$, copper $\left(\mathrm{r}=0.874^{* *}\right)$ and Zinc $\left(\mathrm{r}=0.897^{* *}\right)$. Chromium significantly $(\mathrm{P}<0.01)$ and positively correlated with copper $\left(\mathrm{r}=0.976^{* *}\right)$ and $\mathrm{Zinc}\left(\mathrm{r}=0.977^{* *}\right)$. Copper followed the same trend where it significantly and correlated with Zinc $(\mathrm{r}=0.993 * *)$.

Table 1: Concentration of Heavy Metals $(\mathrm{Cr}, \mathrm{Cd}, \mathrm{Cu}, \mathrm{Zn})$ in Dump sites and Adjacent (Control) sites

\begin{tabular}{|c|c|c|c|c|c|}
\hline \multirow[t]{2}{*}{ Dumpsites } & \multicolumn{2}{|c|}{ Heavy } & \multicolumn{2}{|c|}{ Metals (Mg//Kg) } & \\
\hline & Cd & $\mathrm{Cr}$ & $\mathbf{C u}$ & $\mathbf{Z n}$ & \\
\hline Irette & 5.21 & 2.90 & 126.20 & 17.00 & \\
\hline Ogbaku & 6.00 & & 2.41 & 132.25 & 18.00 \\
\hline Orogwe & 7.20 & & 3.21 & 155.23 & 22.07 \\
\hline Nekede & 6.90 & & 4.80 & 29.10 & 33.64 \\
\hline Akwakuma & 3.70 & & 2.00 & 105.74 & 15.73 \\
\hline Mean & 5.80 & & 3.06 & 109.70 & 21.29 \\
\hline STD & 1.41 & & 1.08 & 73.64 & 7.30 \\
\hline $\mathrm{CV}(\%)$ & 24.31 & & 35.29 & 45.53 & 34.29 \\
\hline \multicolumn{6}{|c|}{ Adjacent (Control) Sites } \\
\hline Irette & 0.40 & & 0.60 & 16.30 & 2.80 \\
\hline Ogbaku & 0.13 & & 0.32 & 19.40 & 2.61 \\
\hline Orogwe & 0.10 & & 1.14 & 11.10 & 2.63 \\
\hline Nekede & 0.04 & & 1.50 & 29.10 & 4.28 \\
\hline Akwakuma & 0.41 & & 0.08 & 13.80 & 3.86 \\
\hline Mean & 0.22 & & 0.73 & 17.94 & 3.24 \\
\hline STD & 0.18 & & 0.59 & 6.95 & 0.78 \\
\hline $\mathrm{CV}(\%)$ & 81.82 & & 80.82 & 38.75 & 24.07 \\
\hline LSD & 0.001 & & 0.001 & 0.003 & 0.004 \\
\hline
\end{tabular}


International Journal of Agriculture and Environmental Research

ISSN: 2455-6939

Volume: 07, Issue: 02 "March-April 2021"

Table 2: Concentration of Heavy Metals $(\mathrm{Cr}, \mathrm{Cd}, \mathrm{Cu}, \mathrm{Zn})$ in Amaranthus) at Dumpsites and Adjacent (Control) Sites

\begin{tabular}{llccc}
\hline Dumpsites & \multicolumn{4}{c}{ Heavy } \\
& Cd & Metals $(\mathbf{M g} / \mathbf{K g})$ & $\mathbf{Z n}$ \\
\hline Irette & 12.00 & 7.60 & 22.60 & 55.98 \\
Ogbaku & 7.12 & 3.67 & 30.90 & 72.30 \\
Orogwe & 18.60 & 3.80 & 43.60 & 88.60 \\
Nekede & 14.60 & 12.18 & 55.00 & 97.33 \\
Akwakuma & 5.16 & 3.21 & 20.22 & 44.33 \\
Mean & 11.50 & 7.21 & 34.46 & 59.82 \\
STD & 5.47 & 3.59 & 14.68 & 35.15 \\
CV(\%) & 37.1 & 46.1 & 37.8 & 58.76 \\
& & & & \\
& & & & \\
Irette & & & & \\
Ogbaku & 0.08 & 0.01 & 0.17 & 0.38 \\
Orogwe & 0.08 & 0.01 & 0.26 & 0.50 \\
Nekede & 0.22 & 1.08 & 0.92 & 0.70 \\
Akwakuma & 0.12 & 1.09 & 0.99 & 0.78 \\
Mean & 0.09 & 0.07 & 0.10 & 0.21 \\
STD & 0.12 & 0.05 & 0.49 & 0.51 \\
CV(\%) & 0.06 & 0.04 & 0.43 & 0.21 \\
LSD & 43.4 & 70.5 & 92.3 & 41.18 \\
\hline
\end{tabular}


International Journal of Agriculture and Environmental Research

ISSN: 2455-6939

Volume: 07, Issue: 02 "March-April 2021"

Table 3: Mean Concentration of Heavy Metals in Dumpsites and Adjacent (Control) sites

\begin{tabular}{lcccc}
\hline & Cd & Cr & Cu & Zn \\
\hline Dump site & 5.80 & 3.06 & 109.70 & 21.29 \\
Adjacent Sites (Control) 0.22 & 0.73 & 17.94 & 3.24 \\
LSD(0.05) & 0.001 & 0.001 & 0.003 & 0.004 \\
\hline
\end{tabular}

Table 4: Mean concentration of Heavy metals in Vegetable (Amaranth) at dump sites and adjacent sites (Control)

\begin{tabular}{lllll}
\hline & Cd & Cr & Cu & Zn \\
\hline Dumpsite & 11.50 & 7.21 & 34.46 & 59.82 \\
Adjacent sites (Control) & 0.12 & 0.05 & 0.49 & 0.51 \\
LSD(0.05) & 0.002 & 0.002 & 0.001 & 0.009 \\
\hline
\end{tabular}

Table 5: Correlation Coefficient (r) matrix for heavy metals in the vegetable (amaranth) and dumpsite soils

\begin{tabular}{lllll}
\hline & $\mathbf{C d}$ & $\mathbf{C r}$ & $\mathbf{C u}$ & $\mathbf{Z n}$ \\
\hline $\mathrm{Cd}$ & 1 & & & \\
$\mathrm{Cr}$ & $0.920^{* *}$ & 1 & & \\
$\mathrm{Cu}$ & $0.874 * *$ & $0.976^{* *}$ & 1 & \\
$\mathrm{Zn}$ & $0.897 * *$ & $0.977 * *$ & $0.993 * *$ & 1 \\
\hline
\end{tabular}

** Significant at $\mathrm{P}<0.01$ level

The positive correlation observed in this study indicates that increasing heavy metals in the dumpsite soils significantly resulted to increased concentration of heavy metals in the vegetable (amaranth). Alloway (1994) made similar observations of significant correlation of soil heavy metals with those of the vegetable in his study.

\section{CONCLUSION}

Heavy Metal contents of soil and vegetable. Samplers in dump sites are significantly higher than adjacent (Control) sites. Therefore, consumption of vegetables grown in dump sites soils should be discouraged because it can create health hazard. Adequate refuse disposal mechanism should 
International Journal of Agriculture and Environmental Research

ISSN: 2455-6939

Volume: 07, Issue: 02 "March-April 2021"

be put in place. Waste sorting into biodegradable and non-biodegradable before disposal should be encouraged.

\section{REFERENCES}

Awokunmi, E.E., S.S. Asaolu and K.O. Ipinmorati (2010). Effect of Leaching on heavy metals concentration of soil in some dumpsite Afr. J. Environ. Sci. Technol., 4: 495 - 499.

Begum, A., Ramaiah, M., Harikrisna., khan, I. and Veena, K. (2009). Heavy metal pollution and chemical profile of cauvery river water. E-Journal of chemistry, 6 (1): $47-52$.

Demirbas, A. (2011): Waste Management, Waste resource Facilities and Waste Conservation Processes Energy Conservation and Management 52(2) 1280 - 1287.

F.A. Aekola, N. Salami, S.O. Lawal, Research Communications in chemistry, 2008, 1:1, $24-30$.

Nyle, C.B and R.W.Ray, 1999. The Nature and Properties of Soils. $12^{\text {th }}$ Edn., Prentice Hall, USA, Pp: $743-785$

Odukoya, A.M. (2015). Contamination assessment of toxic elements in soil within and around two dumpsites in Lagos, Nigeria. Ife Journal of Science, 17(2): 351 - 361.

Odukoya, O.O., Bamgbose .O and Arowolo, T. A. (2000). Heavy metals in topsoil of Abeokuta dumpsites. Journal of pure and Applied Science, 6(4): $467-472$.

Ofomata, G.E.K. (1975): Nigeria in Maps: Eastern State. Ethiope Publishing Housing Publishers, Benin City. 146pp.

Smith, C.J., Hopmans P. and F.J. Cook, (1996). Accumulation of $\mathrm{Cr}, \mathrm{Ph}, \mathrm{Cu}, \mathrm{Ni}, \mathrm{Zn}$ and $\mathrm{Cd}$ in soil following irrigation with treated urban effluent in Australia Environ. Pollut, 94: 317 $-323$

Voet, E., Guinee, B. and Udode, H. (2008). Heavy metals; A problem solved? Dordrecht, Netherlands: Kluwer Academic. Pp 4.

WHO (1996) Permissible limits of heavy metals in soil and plants. (Geneva: World Health Organization), Switzerland. 